\title{
HUBUNGAN ASUPAN ZAT GIZI DAN STATUS GIZI TERHADAP KEJADIAN MENSTRUASI DINI PADA SISWI SMPN 1 KABAENA TIMUR
}

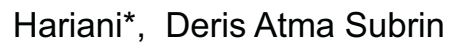 \\ Jurusan Gizi Poltekkes Kemenkes Kendari \\ *Email: harianiani455@yahoo.com
}

\begin{abstract}
Early menstruation in adolescents can be influenced by nutritional status and nutrients consumed by teenagers. This study aims to determine the relationship of nutrient intake and nutritional status on the incidence of early menstruation at SMPN 1 East Kabaena. This research is descriptive analytic with Cross Sectional Study. The population in this study were all students of SMPN 1 East Kabaena as many as 94 people. Sampling technique was purposive sampling. Data were obtained using a questionnaire and anthropometric measurements. Data were analized by using Chi-square test. Results shows that from 42 adolescents who consumed enough energy, there were 25 people (59.5\%) experienced early menstruation, and from 38 adolescents who consumed less protein, there were 29 people (76.3\%) experienced early menstruation. While the 33 adolescents who consumed less fat, there were 25 people (75.8\%) experienced early menstruation, and of 37 teenagers who consumed more carbohydrates, there were 24 people (64.9\%) had normal menstruation, while from 37 teenagers who had over-nutrition status, there were 24 people (60.0\%) had normal menstruation. The results show that there is a relationship between nutritional intake and nutritional status with the incidence of early menstruation in female students at SMPN 1 East Kabaena.
\end{abstract}

Keywords : Nutritional Status and Early Menstruation

\section{ABSTRAK}

Menstruasi dini pada remaja dapat dipengaruhi oleh status gizinya dan nutrisi yang dikonsumsi oleh remaja. Penelitian ini bertujuan untuk mengetahui hubungan asupan zat gizi dan status gizi terhadap kejadian menstruasi dini pada siswi SMPN 1 Kabaena Timur. Penelitian ini merupakan penelitian deskriptif analitik dengan Cross Sectional Study. Populasi pada penelitian ini adalah seluruh siswi SMPN 1 Kabaena Timur sebanyak 94 orang. Pengambilan sampel dengan Purposive Sampling. Data diperoleh menggunakan kuesioner dan pengukuran antropometri. Analisis data menggunakan uji ChiSquare. Hasil yang diperoleh yakni dari 42 remaja yang konsumsi energinya cukup, terdapat 25 orang (59,5\%) mengalami menstruasi dini, dan dari 38 remaja yang konsumsi proteinnya kurang, terdapat 29 orang (76,3\%) mengalami menstruasi dini. Sedangkan dari 33 remaja yang konsumsi lemaknya kurang, terdapat 25 orang $(75,8 \%)$ mengalami menstruasi dini, dan dari 37 remaja yang konsumsi Karbohidratnya lebih, terdapat 24 orang (64,9\%) mengalami menstruasi normal, sedangkan dari 37 remaja yang status gizinya lebih, terdapat 24 orang (60,0\%) mengalami menstruasi normal. Hasil penelitian menunjukkan ada hubungan asupan gizi dan status gizi dengan kejadian menstruasi dini pada siswi SMPN 1 Kabaena Timur.

Kata Kunci : Status Gizi dan Menstruasi Dini

\section{PENDAHULUAN}

World Health Organization (WHO), mendefinisikan remaja merupakan individu yang sedang mengalami masa peralihan yang secara berangsur-angsur mencapai kematangan seksual, mengalami kematangan perubahan jiwa dari jiwa kanak-kanak menjadi dewasa dan mengalami perubahan keadaan ekonomi dari ketergantungan menjadi relatif mandiri tahun ${ }^{1}$.

Masa remaja merupakan masa perubahan antara masa kanak-kanak dan masa dewasa yang meliputi perubahan biologik, perubahan psikologik dan perubahan sosial. Sebagian besar masyarakat dan budaya masa remaja pada umumnya dimulai pada usia 11 sampai dengan 13 tahun dan berakhir pada usia 18-22 tahun. Masa remaja diawali dengan pertumbuhan yang sangat cepat dan biasanya disebut pubertas ${ }^{1}$.
Pubertas adalah dimana sistem reproduksi mengalami kematangan. Pada perubahan organ reproduksi pada remaja laki-laki tanda kepriaan ditandai dengan terjadinya mimpi basah, ereksi, orgasme dan ejakulasi, dan pada perempuan diawali dengan menarche atau menstruasi ${ }^{1}$. Menstruasi adalah darah yang keluar dari vagina wanita sewaktu sehat dan bukan disebabkan oleh melahirkan anak atau karena terluka. Menstruasi menunjukkan bahwa seorang gadis yang sehat dan berfungsi sebagaimana mestinya, sedangkan menstruasi dini adalah menstruasi yang datangnya lebih awal di bawah usia 10 tahun $^{1}$. Menstruasi yang pertama terjadi yang merupakan ciri khas kedewasaan seseorang wanita yang sehat dan tidak hamil ${ }^{2}$.

Akhir-akhir ini, remaja putri sering mengalami menstruasi dini, dimana usia rata-rata saat menstruasi dimulai adalah antara 12-13 tahun, tetapi 
pada sebagian kecil remaja putri yang tampak normal, menarche mungkin muncul pada usia sedini 10 tahun atau selambat 16 tahun $^{3}$.

Masalah yang sering terjadi pada remaja adalah kurangnya asupan gizi yang mengakibatkan menderita kurang gizi yaitu terlalu kurus (Kurang Energi Kronik) dan dapat terkena anemia karena kekurangan zat besi, disamping itu masalah sering muncul adalah kelebihan asupan gizi yang dapat menyebabkan obesitas. Hal-hal tersebut sangat mempengaruhi keadaan tubuh dan sistem produksi hormon yang berkaitan erat dengan terjadinya menarche $e^{4}$.

Status gizi remaja wanita sangat mempengaruhi terjadinya menstruasi, adanya keluhan-keluhan selama menarche maupun lamanya hari menarche, secara psikologi wanita remaja yang pertama kali mengalami haid akan mengeluh rasa nyeri, kurang nyaman, tetapi pada beberapa remaja keluhankeluhan tersebut tidak dirasakan,hal ini dipengaruhi oleh nutrisi yang adekuat ${ }^{5}$.

Selain itu, menstruasi dini pada remaja dapat meningkatkan jumlah angka pernikahan, hal ini karena saat mulai mengalami menstruasi berarti sudah berisiko menjalani proses kehamilan, dan apabila remaja tidak ditanamkan dengan pendidikan seksualitas yang memadai akan terjadi kehamilan yang tidak diinginkan ${ }^{6}$.

Dari beberapa penelitian sejak 100 tahun terakhir menunjukkan bahwa ada kecenderungan semakin cepatnya remaja mengalami menstruasi. Pada tahun 1860 rata-rata usia remaja mengalami menstruasi adalah 16 tahun 8 bulan dan pada tahun 1975 umur 12 tahun 3 bulan. Adanya penurunan umur menstruasi tersebut disebabkan karena adanya perbaikan gizi, perbaikan pelayanan kesehatan dan lingkungan masyarakat. Semakin cepat seseorang mengalami menstruasi tentu semakin cepat pula ia memasuki masa reproduksi ${ }^{7}$. Menstruasi sangat erat hubungannya dengan masa puncak kurva kecepatan penambahan tinggi badan. Masa ini ditentukan oleh berbagai faktor, salah satunya adalah status gizi .

Waryana (2010) juga mengemukakan bahwa terdapat jumlah tertentu lemak tubuh dengan mulai dan berlangsungnya menstruasi ${ }^{1}$. Teori ini menekankan bahwa menstruasi terjadi pada berat badan tertentu dari pada usia tertentu pada seorang wanita, menstruasi yang datang lebih awal biasanya disebabkan oleh beberapa faktor lain, diantaranya, adalah berat badan berlebihan, aktivitas fisik dan genetik. Selain itu dipengaruhi oleh rangsanganrangsangan kuat seperti film, buku-buku bacaan dan majalah orang dewasa yang dapat mempercepat menstruasi lebih dini.

Untuk pertumbuhan normal, tubuh memerlukan nutrisi yang memadai, kecukupan, energi, protein dan ketersediaan semua nutrisi esensial menjadi basis pertumbuhan. Asupan zat gizi akan mempengaruhi pertumbuhan tubuh, dan bila tidak adekuat, akan menyebabkan seluruh unit fungsional remaja ikut terkena dampaknya, seperti derajat metabolisme, tingkat aktivitas, penampilan fisik, dan maturasi seksual. Maturasi seksual seorang wanita ditandai dengan terjadinya menstruasi di usia remaja ${ }^{8}$.

Usia untuk mencapai fase terjadinya menarche dipengaruhi oleh banyak faktor antara lain faktor suku, genetik, sosial, sekonomi, dan lain-lain. Di Inggris usia rata-rata untuk mecapai menstruasi adalah 13,1 tahun, sedangkan suku Bunding di Papua, menarche dicapai pada usia 18,8 tahun $^{3}$.

Di Indonesia gadis remaja pada waktu menstruasi dini bervariasi antara 10-16 tahun dan rata-rata menarche 12,5 tahun, usia menstruasi dini di daerah perkotaan dari pada yang tinggal di desa dan juga lebih lambat wanita yang kerja berat ${ }^{7}$.

Berdasarkan penelitian pendahuluan yang dilakukan di SMPN 1 Kabaena Timur menunjukan bahwa dari 10 siswa SMP kelas I terdapat $20 \%$ orang yang tingkat asupan energi dan protein dalam kategori kurang $50 \%$ yang tingkat asupan energy dan protein dalam kategori lebih dan 30\% tingkat asupan energi, dan protein dalam kategori normal. Sedangkan status gizi sebagian besar $60 \%$ dalam kategori lebih dan $40 \%$ dalam kategori normal.

Berdasarkan data yang diperoleh dari SMPN 1 Kabaena Timur pada tahun ajaran 2013/2014, terdaftar 168 siswa yang terdiri dari 94 perempuan dan 74 laki-laki, jumlah siswa kelas I sebanyak 65 orang, kelas II sebanyak 58 orang dan kelas III sebanyak 45 orang. Di SMPN 1 Kabaena Timur belum pernah dilakukan pengukuran asupan maupun status gizi pada remaja.

\section{METODE}

Jenis penelitian yang dilakukan merupakan penelitian deskriptif analitik dengan Cross Sectional Study. Penelitian ini telah dilaksanakan pada bulan September di SMPN 1 Kabaena Timur Tahun 2013.

Populasi pada penelitian ini adalah seluruh siswi SMPN 1 Kabaena Timur Tahun 2011 sebanyak 94 orang. Sampel dalam penelitian ini adalah siswi SMPN 1 Kabaena Timur Tahun 2013 sebanyak 94 orang. Teknik pengambilan sampel dilakukan dengan menggunakan Purporsive Sampling dengan kriteria sampel yaitu siswi usia 11-13 Tahun, terdaftar sebagai siswi di SMPN 1 Kabaena Timur Tahun 2013, bersedia untuk menjadi sampel, dan mampu berkomunikasi dengan baik.

Data karakteristik sampel meliputi umur diperoleh dari hasil wawancara menggunakan kuesioner. Data asupan zat gizi (energi dan protein) diperoleh dari 
hasil wawancara menggunakan formulir Recall 2x24 jam. Data status gizi diperoleh dengan cara melakukan pengukuran antopometri berdasarkan IMT yaitu berat badan menggunakan timbangan injak dengan ketelitian 0,5 gr dan tinggi badan menggunakan mikrotoise. Data kejadian menstruasi dini diperoleh dari hasil wawancara menggunakan kuesioner.

Untuk menganalisis "hubungan asupan zat gizi dan status gizi terhadap kejadian menstuasi dini" digunakan analisis univariat dan bivariat kemudian digunakan "Uji Chi-Square" 9 .

\section{HASIL DAN PEMBAHASAN}

Pada penelitian ini sampel yang teliti sebanyak 94 responden yang merupakan siswi SMPN 1 Kabaena Timur Tahun 2013. Adapun distribusi sampel menurut umur responden, asupan anergi, asupan protein, status gizi dan kejadian menstruasi dapat dilihat pada tabel 1.

Hubungan konsumsi energi dengan kejadian menstruasi dini pada remaja dapat dilihat pada tabel 2. Tabel 2 menunjukan bahwa dari 42 remaja yang konsumsi energinya cukup, sebagian besar yaitu $59,5 \%$ mengalami menstruasi dini, kemudian dari 24 remaja yang konsumsi energinya kurang sebagian besar yaitu $75,0 \%$ mengalami menstruasi dini, selanjutnya dari 18 remaja yang konsumsi energinya lebih, sebagian besar yaitu 64,3\% mengalami menstruasi normal.

Berdasarkan analisis statistik dengan
Tabel 1. Distribusi responden menurut umur, Asupan energi, Asupan Protein,status gizi, dan kejadian menstruasi

\begin{tabular}{ccc}
\hline Variabel & $\mathbf{N}$ & $\%$ \\
\hline- Umur responden & & \\
12 tahun & 20 & 21,3 \\
13 tahun & 74 & 78,7 \\
\hline - Asupan energi & & \\
$\quad$ Lebih & 28 & 29,8 \\
$\quad$ Cukup & 42 & 44,7 \\
$\quad$ Kurang & 24 & 25,5 \\
\hline - Asupan Protein & & \\
$\quad$ Lebih & 28 & 24,5 \\
$\quad$ Cukup & 33 & 35,1 \\
$\quad$ Kurang & 18 & 40,4 \\
\hline - Status Gizi & & \\
$\quad$ Gemuk & 40 & 42,6 \\
$\quad$ Normal & 37 & 39,3 \\
$\quad$ Kurus & 17 & 18,1 \\
\hline Kejadian menstruasi & & \\
Menstruasi normal & 53 & 56,4 \\
$\quad$ Menstruasi dini & 14 & 43,6 \\
\hline
\end{tabular}

menggunakan uji Chi-Square diperoleh nilai $p=0,015$ sehingga dapat disimpulkan bahwa ada hubungan antara konsumsi energi dengan kejadian menstruasi dini.

Kebutuhan energi seseorang adalah konsumsi energi dari makanan yang diperlukan untuk menutupi pengeluaran energi seseorang bila mempunyai ukuran dan komposisi tubuh dengan tingkat aktivitas yang sesuai dengan kesehatan jangka panjang, dan yang memungkinkan pemeliharaan aktifitas fisik yang dibutuhkan secara sosial dan ekonomi ${ }^{10}$.

Tabel 2 . Hubungan Konsumsi Energi dengan Kejadian Menstruasi Dini

\begin{tabular}{cccccccc}
\hline & \multicolumn{3}{c}{ Menstruasi Dini } & \multicolumn{2}{c}{ Total } & \multirow{2}{*}{$\mathbf{P}$} \\
\cline { 2 - 6 } Konsumsi Energi & $\begin{array}{c}\text { Menstruasi } \\
\text { Normal }\end{array}$ & \multicolumn{2}{c}{$\begin{array}{c}\text { Menstruasi } \\
\text { Dini }\end{array}$} & & \\
\cline { 2 - 7 } & $\mathbf{n}$ & $\mathbf{\%}$ & $\mathbf{n}$ & $\mathbf{\%}$ & $\mathbf{n}$ & $\mathbf{\%}$ & \\
\hline Lebih & 18 & 64,3 & 10 & 35,7 & 18 & 100 & \\
Cukup & 17 & 40,5 & 25 & 59,5 & 42 & 100 & \multirow{2}{*}{0,015} \\
Kurang & 6 & 25,0 & 18 & 75,0 & 24 & 100 & \\
\hline Total & $\mathbf{5 3}$ & $\mathbf{5 6 , 4}$ & $\mathbf{4 1}$ & $\mathbf{4 3 , 6}$ & $\mathbf{9 4}$ & $\mathbf{1 0 0}$ & \\
\hline
\end{tabular}

Hasil penelitian menunjukan bahwa dari 94 sampel sebagian besar yaitu 44,7\% asupan energinya cukup dan sebagian kecil 25,5\% asupan energinya kurang. Konsumsi energi yang kurang pada sampel karena berdasarkan penelitian ditemukan asupan energi sampel tidak sesuai kebutuhannya dengan frekuensi makan utama 2 kali bahkan 1 kali dalam sehari, kemudian hasil penelitian juga menunjukan bahwa juga terdapat siswi yang asupan energinya lebih, hal ini karena asupan energi melebihi kebutuhannya, dan juga akibat dari kebiasaan mengkonsumsi makananmakanan cemilan seperti coklat dan gorenggorengan. Hubungan konsumsi protein dengan kejadian menstruasi dini pada remaja dapat dilihat pada tabel 3 berikut:

Tabel 3.Hubungan Konsumsi Protein dengan Kejadian Menstruasi Dini

\begin{tabular}{cccccccc}
\hline \multirow{2}{*}{$\begin{array}{c}\text { Konsumsi } \\
\text { Protein }\end{array}$} & \multicolumn{3}{c}{ Menstruasi Dini } & \multicolumn{2}{c}{ Total } & \multirow{2}{*}{$\mathbf{P}$} \\
\cline { 2 - 6 } & $\begin{array}{c}\text { Menstruasi } \\
\text { Normal }\end{array}$ & \multicolumn{2}{c}{$\begin{array}{c}\text { Menstruasi } \\
\text { Dini }\end{array}$} & & & \\
\cline { 2 - 6 } & $\mathbf{n}$ & $\mathbf{\%}$ & $\mathbf{n}$ & $\mathbf{\%}$ & $\mathbf{n}$ & $\mathbf{\%}$ & \\
\hline Lebih & 14 & 60,9 & 9 & 39,1 & 23 & 100 & \\
Cukup & 18 & 54,5 & 15 & 45,5 & 33 & 100 & 0 \\
Kurang & 9 & 23,7 & 29 & 76,3 & 38 & 100 & 0,005 \\
\hline Total & $\mathbf{5 3}$ & $\mathbf{5 6 , 4}$ & $\mathbf{4 1}$ & $\mathbf{4 3 , 6}$ & $\mathbf{9 4}$ & $\mathbf{1 0 0}$ & \\
\hline
\end{tabular}


Tabel 3 menunjukan bahwa dari 38 remaja yang konsumsi proteinnya kurang, sebagian besar yaitu $76,3 \%$ mengalami menstruasi dini, kemudian dari 33 remaja yang konsumsi proteinnya cukup sebagian besar yaitu $54,5 \%$ mengalami menstruasi normal. Selanjutnya dari 23 remaja yang konsumsi proteinnya lebih, sebagian besar yaitu $60,9 \%$ mengalami menstruasi normal
Berdasarkan analisis statistik dengan menggunakan uji Chi-Square diperoleh nilai $p=0,005$, sehingga dapat disimpulkan bahwa ada hubungan antara konsumsi protein dengan kejadian menstruasi dini.

Hubungan status gizi dengan kejadian menstruasi dini pada remaja dapat dilihat pada tabel 4 berikut:

Tabel 4. Hubungan Status Gizi dengan Kejadian Menstruasi Dini

\begin{tabular}{cccccccc}
\hline & \multicolumn{4}{c}{ Menstruasi Dini } & \multicolumn{2}{c}{ Total } & \multirow{2}{*}{$\mathbf{P}$} \\
\cline { 2 - 6 } Status Gizi & $\begin{array}{c}\text { Menstruasi } \\
\text { Normal }\end{array}$ & \multicolumn{2}{c}{$\begin{array}{c}\text { Menstruasi } \\
\text { Dini }\end{array}$} & & & \\
\cline { 2 - 6 } & $\mathbf{n}$ & $\mathbf{\%}$ & $\mathbf{n}$ & $\mathbf{\%}$ & $\mathbf{n}$ & $\mathbf{\%}$ & \\
\hline Gemuk & 24 & 60,0 & 16 & 40,0 & 40 & 100 & \\
Normal & 12 & 32,4 & 25 & 67,6 & 37 & 100 & \multirow{2}{*}{$=0,022$} \\
Kurus & 5 & 29,4 & 12 & 70,6 & 17 & 100 & \\
\hline Total & $\mathbf{5 3}$ & $\mathbf{5 6 , 4}$ & $\mathbf{4 1}$ & $\mathbf{4 3 , 6}$ & $\mathbf{9 4}$ & $\mathbf{1 0 0}$ & \\
\hline
\end{tabular}

Tabel 4 menunjukan bahwa dari 37 remaja yang status gizinya gemuk, sebagian besar yaitu 60,0\% mengalami menstruasi normal, kemudian dari 37 remaja yang status gizinya normal, sebagian besar yaitu $67,6 \%$ mengalami menstruasi dini. Selanjutnya dari 17 remaja yang status gizinya kurus, sebagian besar yaitu 70,6\% mengalami menstruasi dini.

Berdasarkan analisis statistik dengan menggunakan uji Chi-Square diperoleh nilai $p=0,022$, sehingga dapat disimpulkan bahwa ada hubungan antara status gizi dengan kejadian menstruasi dini.

Porverawati mengemukakan bahwa status gizi adalah keadaan keseimbangan dalam bentuk variabel tertentu, atau perwujudan dari nutriture dalam bentuk variabel tertentu ${ }^{11}$.

Status gizi merupakan keseimbangan antara asupan makanan dengan kebutuhan zat gizi. Status gizi baik atau optimal terjadi bila tubuh memperoleh cukup zat-zat gizi yang digunakan secara efisien, sehingga memungkinkan pertumbuhan fisik, kemampuan kerja dan kesehatan secara umum pada tingkat setinggi mungkin. Status gizi kurang terjadi bila tubuh memperoleh zat-zat gizi dalam jumlah berlebihan sehingga menimbulkan efek toksis atau membahayakan. Pada status gizi kurang maupun lebih terjadi gangguan gizi ${ }^{10}$.

Hasil penelitian menunjukan bahwa dari 94 sampel sebagian besar yaitu $42,6 \%$ status gizinya gemuk dan sebagian kecil yaitu $18,1 \%$ status gizinya kurus. Konsumsi makanan berpengaruh dengan status gizi. Suatu hal yang dapat mempengaruhi pembentukan hormon salah satunya adalah asupan gizi, dengan asupan gizi yang baik dapat mempercepat pembentukan hormon-hormon yang mempengaruhi datangnya menarche, sehingga dengan perbaikan gizi atau asupan gizi yang baik dapat menyebabkan umur haid pertama menjadi lebih dini. Pada penelitian ini penulis menggunakan indeks BB/TB dalam menentukan status gizi remaja, hal ini karena indeks BB/TB merupakan indikator yang baik untuk menilai status gizi saat ini.

Status gizi baik atau status gizi optimal terjadi bila tubuh memperoleh cukup zat-zat gizi yang digunakan secara efisien, sehingga pertumbuhan fisik, perkembangan otak, kemampuan kerja dan kesehatan secara umum meningkat. Status gizi kurang terjadi bila tubuh mengalami kekurangan satu atau lebih zat-zat gizi essensial. Status gizi lebih terjadi bila tubuh memperoleh zat-zat gizi dalam jumlah berlebihan, sehingga menimbulkan toksis atau membahayakan ${ }^{10}$.

Hasil penelitian menunjukan bahwa dari 94 sampel sebagian besar yaitu $56,4 \%$ mengalami menstruasi normal. Mestruasi adalah haid yang pertama terjadi, yang merupakan ciri khas kedewasaan seorang wanita yang sehat dan tidak hamil ${ }^{12}$. Status gizi remaja wanita sangat mempengaruhi terjadinya menstruasi baik dari faktor usia terjadinya menstruasi, adanya keluhan-keluhan selama menstruasi maupun lamanya hari menstruasi. Secara psikologis wanita remaja yang pertama sekali mengalami haid akan mengeluh rasa nyeri, kurang nyaman, dan mengeluh perutnya terasa begah atau tegang. Tetapi pada beberapa remaja keluhan-keluhan tersebut tidak dirasakan, hal ini dipengaruhi oleh nutrisi yang adekuat yang biasa dikonsumsi, selain olahraga yang teratur ${ }^{13}$.

Nutrisi mempengaruhi kematangan seksual pada gadis yang mendapat menstruasi pertama lebih dini, mereka cenderung lebih berat dan lebih tinggi pada saat menstruasi pertama dibandingkan dengan mereka yang belum menstruasi pada usia yang sama. Sebaliknya pada gadis yang menstruasinya terlambat, beratnya lebih ringan daripada yang sudah menstruasi pada usia yang sama, walaupun tinggi badan (TB) mereka sama. Pada umumnya, mereka menjadi matang lebih dini akan memiliki body mass index (indeks masa tubuh, IMT) yang lebih tinggi dan mereka yang matang terlambat memiliki IMT lebih kecil pada usia yang sama ${ }^{3}$. Penyimpanan lemak 
sebagai cadangan energi dalam waktu yang lama bisa mengakibatkan terjadinya kelebihan berat badan atau obesitas ${ }^{8}$.

Hasil penelitian menunjukan bahwa dari 42 remaja yang konsumsi energinya cukup, sebagian besar yaitu $59,5 \%$ mengalami menstruasi dini, kemudian dari 24 remaja yang konsumsi energinya kurang sebagian besar yaitu $75,0 \%$ mengalami menstruasi dini, selanjutnya dari 18 remaja yang konsumsi energinya lebih, sebagian besar yaitu $64,3 \%$ mengalami menstruasi normal. Berdasarkan analisis statistik, dapat disimpulkan bahwa ada hubungan antara konsumsi energi dengan kejadian menstruasi dini.

Adanya hubungan antara asupan energi dengan kejadian menstruasi dini pada remaja disebabkan karena berdasarkan hasil penelitian pada remaja yang asupan energinya lebih, mempercepat menstruasi dini, dimana hasil penelitian menunjukan pada remaja yang asupannya lebih, mengalami menstruasi dini, Asupan energi yang lebih dapat dalam tubuh akan disimpan menjadi cadangan lemak, dan lemak merupakan bahan pembentuk hormon wanita yakni hormon progesteron dan esterogen, keadaan ini amenggambarkan bahwa asupan energi memberi pengaruh pada kejadian menstruasi dini.

Pada penelitian ini terlihat bahwa remaja yang asupan proteinnya lebih cenderung mengalami menstruasi dini dibanding yang asupan proteinnya cukup. Makanan yang tinggi protein umumnya tinggi lemak, sehingga apabila mengkonsumsi protein dalam jumlah yang banyak, maka kandungan lemak juga akan semakin banyak, dan lemak merupakan bahan pembentuk hormon progesteron dan esterogen, Kadar esterogen akan meningkat akibat kolesterol tinggi. Bukan hanya lemak dari komposisi tubuh apa saja tetapi sebaliknya dipengaruhi oleh faktor asupan makan dan faktor tidak adanya penyakit melemahkan. Suatu hal yang dapat mempengaruhi pembentukan hormon salah satunya adalah asupan gizi, dengan asupan gizi yang baik dapat mempercepat pembentukan hormon-hormon yang mempengaruhi datangnya menstruasi, sehingga dengan perbaikan gizi atau asupan gizi yang baik dapat menyebabkan umur haid pertama menjadi lebih dini.

Hal ini juga didukung oleh teori yang dikemukakan oleh Waryana, bahwa asupan protein hewani yang kurang akan mempengaruhi penurunan frekuensi puncak Luteinizing Hormon (LH) dan akan mengalami pemendekan fase folikuler rata-rata 3,8 hari 1 . Hal ini telah diteliti pada 9 orang non vegetarian yang diberi diet mengandung protein hewani (daging) ternyata fase folikuler memanjang dan Follicle stimulating hormone $(\mathrm{FSH})$ pun meningkat ${ }^{1}$.

Adanya hubungan status gizi dengan menstruasi dini disebabkan karena hasil penelitian menunjukan bahwa remaja yang status gizinya lebih cenderung mengalami menstruasi dini dibanding remaja yang status gizinya kurang ataupun cukup. Hal ini didukung oleh teori yang dikemukakan oleh Waryana yang mengemukakan bahwa terdapat jumlah tertentu lemak tubuh dengan mulai dan berlangsungnya menstruasi'. Teori ini menekankan bahwa menarche terjadi pada berat badan tertentu dari pada usia tertentu pada seorang wanita, menstruasi yang datang lebih awal biasanya disebabkan oleh beberapa faktor lain, diantaranya, adalah berat badan berlebihan, aktivitas fisik dan genetik. Selain itu dipengaruhi oleh rangsangan-rangsangan kuat seperti film, buku-buku bacaan dan majalah orang dewasa yang dapat mempercepat menstruasi lebih dini.

Menstruasi pada awalnya terjadi secara tidak teratur sampai mencapai umur 18 tahun. Titik kritis ukuran antropometri pencetus menstruasi dini (menarche) adalah berat badan $40 \mathrm{~kg}$ dan tinggi badan $148 \mathrm{~cm}$. Menurut Swenne dalam Waryana mengemukakan bahwa terdapat hubungan antara massa tubuh dengan kejadian menstruasi dini, begitu pula dengan BMI dengan usia menstruasi ${ }^{1}$.

\section{KESIMPULAN DAN SARAN}

a. Kesimpulan

Berdasarkan hasil penelitian dapat dismpulkan hal-hal sebagai berikut:

1. Ada hubungan asupan energi dengan kejadian menstruasi dini pada siswi SMPN 1 Kabaena Timur dengan nilai $p=0,015$.

2. Ada hubungan asupan protein dengan kejadian menstruasi dini pada siswi SMPN 1 Kabaena Timur, dengan nilai $p=0,005$.

3. Ada hubungan status gizi dengan kejadian menstruasi dini pada siswi SMPN 1 Kabaena Timur, dengan nilai $p=0,022$.

b. Saran

Hasil penelitian ini dapat menjadi masukan bagi pemerintah daerah dan instansi terkait dalam menentukan kebijakan-kebijakan dalam upaya menanggulangi masalah status gizi lebih dan asupan protein yang kurang pada remaja putri.

\section{DAFTAR PUSTAKA}

1. Waryana. Gizi Reproduksi.Pustaka Rihamma. Yogyakarta, 2010.

2. Ambarwati F, R. Gizi dan Kesehatan Reproduksi. Cakrawala Ilmu. Yogyakarta, 2012.

3. Jamaluddin. Psikologi Perkembangan (Masa Remaja). http://remaja. co.id.6583hnfjd//;jfksd, 2009.

4. Poltekkes Depkes Jakarta. Kesehatan Remaja 
Problem dan Solusinya. Salemba Medika. Jakarta, 2010.

5. Ambarwati F, R. Gizi dan Kesehatan Reproduksi. Cakrawala IImu. Yogyakarta, 2012.

6. Jamaluddin, 2009. Psikologi Perkembangan ( M a s a Remaja). ht t p://remaja . co.id.6583hnfjd//;fksd. Diakses Tanggal 21 Juni 2012.

7. Wibowo.Permasalah Reproduksi Remaja dan A It ernatif Jala $\mathrm{K}$ Keluarnya, http://reproduksi.co.id.67gjk/ki9ojo.jgk. 2008.

8. Soekirman. IImu Gizi Dan Aplikasinya Untuk Keluarga Dan Masyarakat. Direktorat Jendaral
Pendidikan Tinggi Departement Pendidikan $\mathrm{M}$ a s y a $r$ a $k$ a $t$, J a $k$ a $r a$. http://gizi.co.id./67246,djshf./nutri.njxc90.id. 2008.

9. Notoatmodjo S.Metodologi Penelitian. Rineka Cipta.Jakarta, 2005.

10.Almatsier. S. Prinsip Dasar IImu Gizi. Gramedia Pustaka Utama. Jakarta, 2001.

11.Proverawati. IImu Gizi untuk Keperawatan dan Gizi Kesehatan. Nuha Medika. Yogyakarta, 2010.

12.Prasetyawati.Kesehatan Ibu dan Anak (KIA). Nuha Medika. Yogyakarta, 2012.

13.Ambarwati F, R. Gizi dan Kesehatan Reproduksi. Cakrawala Ilmu. Yogyakarta, 2012. 